\title{
Jessica Fortin-Rittberger
}

University of Salzburg, Austria

\section{Berthold Rittberger}

University of Munich, Germany

\begin{abstract}
The European Parliament (EP) has one of the highest proportions of women in its ranks, with over a third in 2009. Although previous research has pointed to the use of proportional representation (PR) in European elections as 'friendlier' to women, few have looked at differences in the types of PR rules in use in each country. In this article, we argue that the conventional wisdom according to which institutional design-the choice of electoral rules - should shape the composition of the EP does not hold, and suggest that the well-documented empirical connection between electoral rules and descriptive representation might in fact be an endogenous rather than a causal relationship.
\end{abstract}

\section{Keywords}

Descriptive representation, electoral rules, European Parliament, gender

\section{Introduction}

The European Parliament (EP) is heralded as one of the most gender-equal elected bodies in the world. One central feature of representation in the EP is its seemingly more egalitarian representation of women than that of its member countries' lower houses. This observation is significant since the presence of women in elected office offers symbolic benefits for gender equality (Phillips, 1995; Pitkin, 1967: 47). It is therefore no surprise that many contributors have attempted to explain why the 
proportion of women in national parliaments is lower than in the EP. Many studies have found that the use of party-based proportional electoral systems in elections for the EP holds a large part of the explanation (Freedman, 2002; Kantola, 2010; Norris, 1997; Vallance and Davis, 1986). Yet, aggregate figures camouflage important differences. Once we disaggregate the combined figures of women's representation by country, we find a much more nuanced picture: while the proportion of female members of the EP (MEPs) outnumbers that of female members of parliament (MPs) in a majority of EU member states, there is a significant number of countries where the proportion of female MPs in the national legislature exceeds that of female MEPs. These differences in patterns of descriptive representation between the EP and national parliaments have received little systematic exploration in the literature to date.

In this article, we take issue with the conventional wisdom according to which 'scholars can make fairly strong and reliable predictions about the results that particular configurations of an electoral system will produce' (Farrell and Scully, 2007: 47) in two respects: first, we will probe whether the conventional wisdom applies to EP elections, and second, whether the empirical connections linking electoral rules to descriptive representation documented in a myriad of previous studies are in fact causal in the case of EP elections. Comparing national parliamentary elections with elections to the EP offers particularly fertile grounds to test these claims. On the one hand, national elections are run on a variety of electoral formulas that tend to be endogenous to party systems, while on the other hand, electoral formulas have been imposed for EP elections, demanding the application of proportional representation (PR). Electoral formulas for EP elections do thus have a distinct exogenous component. Since these elections involve the same political parties and electorates, our research design should be able to uncover the raw effect of electoral institutions on the level of descriptive representation.

The findings of our analyses are twofold. First, we qualify the claim that the use of PR is the reason why women have been more successful in gaining representation in the aggregate in the EP. Electoral rules for EP elections display important variations in some of their features across EU member states, such as in district magnitude, effective thresholds, ballot structures, and the overall proportionality of each system. Despite the use of PR whose principal advantage should be to minimize the distortion between the amount of votes a party receives and the amounts of seats it obtains, we find that on average, EP election outcomes are not more proportional than lower house elections. The higher proportion of women MEPs can therefore not be attributed to the use of the general electoral family of PR. Second, our results indicate that the standard institutional features of electoral systems determining proportionality - electoral formulas, district magnitudes, effective thresholds - are not linked to the level of women's representation in the EP. Furthermore, differences in these features between lower house and EP elections do not explain the gap in representation between these institutions. Our findings therefore question the conventional wisdom according to which institutional design - here the choice of electoral rules - shapes the composition of the EP 
and suggest that the well-documented empirical connection between electoral rules and descriptive representation might in fact be an endogenous rather than a causal relationship.

\section{The national-EP gender gap in the 27 EU countries}

It is a commonly held assumption that the representation of women is more egalitarian in the EP than in the EU member states' lower houses (Freedman, 2002; Kantola, 2010; Norris, 1997; Vallance and Davis, 1986). Figure 1 displays the proportion of female parliamentarians in the EP versus the average proportion of women representatives in EU member states' lower houses of parliament since 1979. When looking at aggregate figures of descriptive representation over time, women consistently achieve a larger share of the seats in the EP compared with the average of national lower houses. In 2009, women represented some $35 \%$ of MEPs while only some $22 \%$ of MPs in the 27 EU countries. This proportion makes the EP the most gender equal body in terms of gender balanced representation among all EU institutions (Kantola, 2010), and it has remained more equal than national lower houses over time, as illustrated in Figure 1.

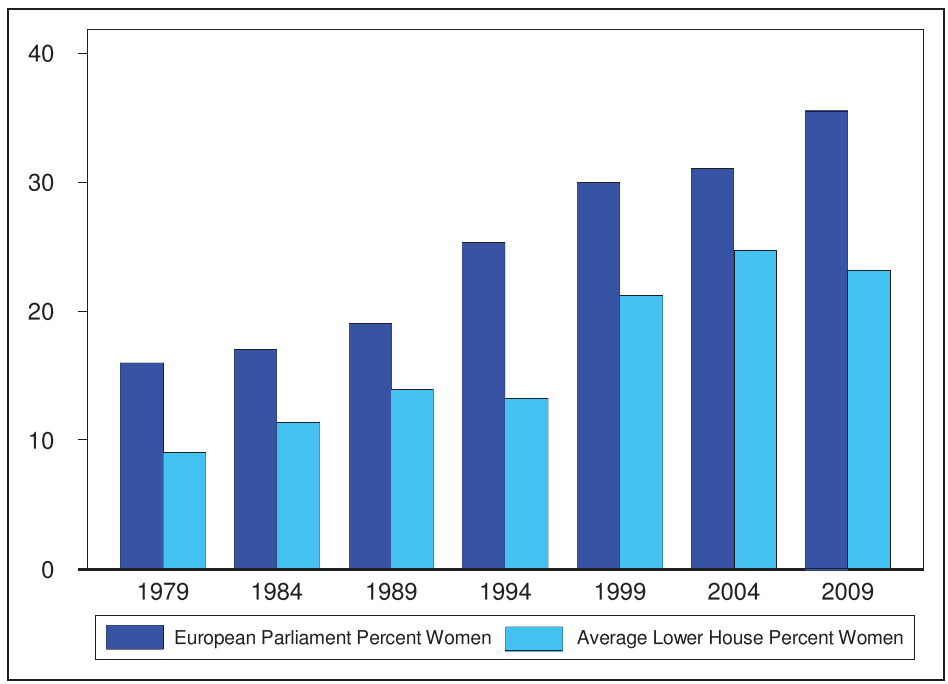

Figure I. National-EP gender gap in aggregate over time.

Note: Figures from 1994, 1999, 2004 and 2009 represent the lower houses in power at the time of the EP election. Lower house figures for 1979 were calculated using the year 1980 in 9 countries, figures for 1984 were calculated using the year 1985 in 10 countries, while figures for 1989 were calculated using the year 1990 in 12 countries.

Source: Interparliamentary Union (IPU), Stockemer (2008), Kantola (2010). 
The existing literature has advanced several arguments to account for the gender gap in female representation between the national and the EU level. The first and most common explanation hinges on the role of families of electoral institutions. Vallance and Davis (1986) argue that some countries have different electoral systems for the two parliaments, and that the effects of these rules explain differences in levels of representation. France, for example, employs a two-round singlemember district (SMD) system to elect MPs to the lower house and PR in EP elections, which results in a higher proportion of women in the EP. This hypothesis is congruent with a large body of literature offering evidence that PR tends to produce more equitable outcomes in terms of gender representation than SMD plurality rules in national parliaments (Beckwith, 1992; Castles, 1981; Caul, 1997, 1999; Darcy et al., 1994; Duverger, 1955; Jones, 2009; Kenworthy and Malami, 1999; Krook, 2010; Lakeman, 1994; Lijphart, 1984, 1999; Matland, 1993; McAllister and Studlar, 2002; Norris, 1985, 2004; Norris and Krook, 2011; Paxton, 1997; Paxton and Hughes, 2007; Paxton and Kunovich, 2003; Reynolds, 1999; Reynolds and Reilly, 1997; Rule, 1987, 1994; Salmond, 2006; Tripp and Kang, 2008; Vengroff et al., 2000; Wangnerud, 2009). Since 1999, elections to the EP employ variations of PR formulas, while national elections are run on a variety of electoral rules and district magnitudes. The prevalent use of PR in EP elections has been credited for the overall higher level of women's representation at the supranational level.

A second explanation found in the literature pertains to the supposed lower importance of EP elections in relation to national parliamentary elections. EP elections are often referred to as 'second order' elections (Reif and Schmitt, 1980), which has led some to argue that becoming an MEP is less competitive than becoming an MP (Kantola, 2010; Stockemer, 2008). However, given the significant rise in powers of the EP in the past decades (Héritier, 2007; Rittberger, 2005), these arguments become less compelling and we would expect the gap between parliamentary representation of women at the domestic and EU level to narrow.

A third set of explanations highlights the supply side and argues that women consider the EP a friendlier environment than their national parliaments (Footitt, 2002; Freedman, 2002). The reasons invoked are the more consensual discussions and less confrontational styles of politics, more structured working hours and the availability of child-care in Brussels and Strasbourg. Fourth, compared to national parliaments, the EP is a newcomer on the scene of parliamentary institutions. With the first direct elections taking place only in 1979, there was no entrenched male hegemony in the institution, nor were there incumbents to defeat in the first elections (Studlar and McAllister, 1991; Studlar and Welch, 1991), hence the increased opportunities for female candidates to succeed (Kantola, 2010). Fifth, the high level of activism of women's movements in the EU has been credited for increasing women's descriptive representation by politicizing the issue of gender-equal representation (Krook, 2002). In particular, the European Women's Lobby has played an active role in campaigning for increased representation of women before each 
EP election since the 1990s. Moreover, the emergence and broadening of gender mainstreaming in EU policy documents has come to include issues related to women in decision-making positions (Pollack and Hafner-Burton, 2000).

While these explanations shed light on women's representation in the aggregate, they fall short on two counts: first, women's representation is not higher in the EP for all EU member states. Second, there is considerable variation across countries regarding the proportion of female parliamentarians sent to Strasbourg and Brussels. Hence, the aggregate figures conceal important differences. When we disaggregate Figure 1 by country, we observe a much more complex picture than that of the EP as an easier-to-win electoral arena for women. Figure 2 presents the difference between the percentage of women in the EP and the percentage of women in each country's lower house in 2009. What is noticeable is the size as well as the large variation in the level of representation between the national and the EU arena. Six countries out of 27 display a smaller proportion of women in the EP than in the national legislature in 2009: Malta, the Czech Republic, Luxembourg, Poland, Slovenia, and Belgium. The figures for these countries challenge the conventional wisdom that it is easier for female candidates to be elected MEP than MP. ${ }^{1}$ Twelve countries had slightly higher proportions of women in the

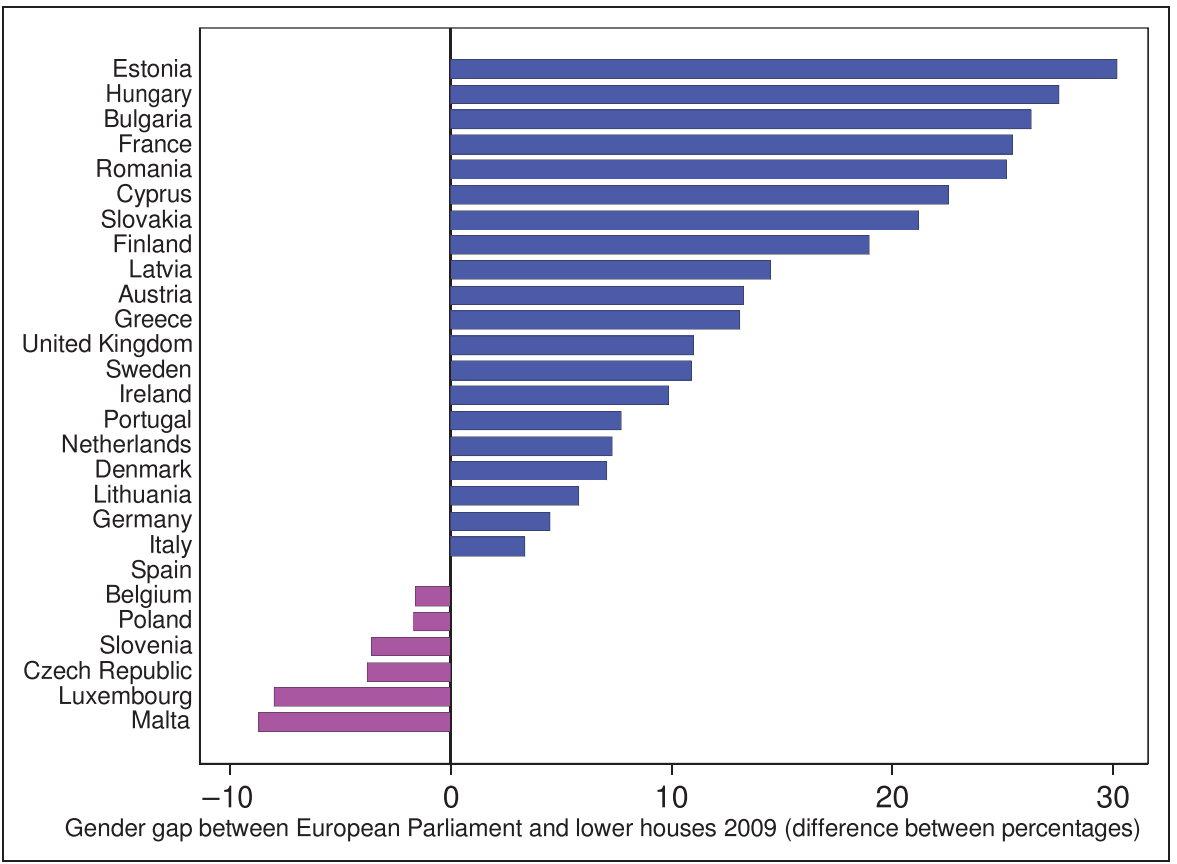

Figure 2. National-EP gender gap (percent in EP minus percent in Lower Houses) 2009. Gender gap between European Parliament and lower houses 2009 (difference between percentages). 
EP than in the domestic lower house (ranging from parity to 10 percentage points), while eight countries had much larger proportions of women in the EP $(20 \%$ or more): Finland, Estonia, Bulgaria, France, Slovakia, Romania, Hungary, and Cyprus.

While the observation that women are better represented in the EP holds true in aggregate figures, the pattern is not systematic enough to simply discard those cases in which the proportion of women is lower in the EP as outliers or anomalies. These differences have received little systematic exploration in the literature and cast doubt on the assumption that obtaining a seat in the EP is an easier feat for women than in a national parliament. ${ }^{2}$ In light of the influential body of research linking electoral systems and descriptive representation, it is reasonable to expect that the different forms of PR employed in EP elections should be linked to the proportion of women in the EP. Moreover, if the effect of institutions is causal, the differences in electoral rules between lower houses and EP should hold some clues as to why patterns of descriptive representation differ between national lower houses and the EP.

\section{Electoral rules and the national-EP gender gap in the $27 \mathrm{EU}$ countries}

While the difference between families of electoral systems in each country and those employed for EP elections is often credited for the overall higher level of female representation in the EP, these assertions were not subjected to rigorous empirical testing beyond the establishment of broad patterns. In fact, studies of descriptive representation in the EP to date have limited their investigations to general categorizations of electoral families (e.g. PR, first-past-the-post, mixed). It has been widely assumed that since some form of PR has been employed in all countries since the 1999 EP elections, the effects of belonging to a particular type of family, here PR, would be similar on descriptive representation across the board. Yet, when we look beyond the general formula to specific features of electoral design like subtypes of electoral formula, average district magnitude, effective thresholds, and ballot structures, we observe considerable differences in the way EP elections transfer votes into seats in each country. As we demonstrate, these variations are so pronounced that EP election results are not always more proportional than those of national elections held under a larger variety of electoral formulas. If it were the case that the use of PR is indeed linked to higher proportions of women elected to parliaments in general, exploring the differences in specific features of electoral institutions should hold a key to explain the large variation in the proportion of women in the EP.

Even though the EP elections in 1999 already saw a convergence towards the application of PR across EU member states, in 2002 a Council decision (2002/772 EC, Euratom) introduced more stringent uniformity rules to elect MEPs in EU member states. ${ }^{3}$ The decision stipulates that EP elections should be held under PR, but that each member state is free to choose whether or not the lists include a 
preferential component, the establishment of constituencies, and whether or not a threshold is to be employed (although no threshold should exceed 5\%) (Farrell and Scully, 2005). Despite these harmonization efforts, EU member states exhibit significant differences in electoral formulas, district magnitudes, and the structure of ballots. For example, among the EU member states, we find different ways through which seats are allocated; some using the methods of the highest average (d'Hondt, Sainte-Laguë, or modified Sainte-Laguë methods) and others using the largest remainders (Hare or Droop quotas). The choice of formula impacts the proportionality of the system - the closeness of the relationship between votes and seats - from the most proportional Sainte-Laguë to the least proportional d'Hondt (Gallagher, 1992; Lijphart, 1986).

Countries have also chosen different types of ballot structures. We find closed, ordered, and open ballot structures, and the single transferable vote (STV) in national elections to the EP. Following a body of research developed for lower house elections (Carey and Shugart, 1995), contributors have investigated how ballot structures are shaping the incentives that MEPs face and the extent to which elections are based on personal or party votes (Bowler and Farrell, 1993; Hix and Hagemann, 2008; Hix and Høyland, 2013). We know much less, however, about how ballot structure shapes who gets elected to the EP (Farrell and Scully, 2005). The literature on the effects of ballot structure on the election of women in national legislative assemblies suggests that closed lists tend to be more advantageous to women than open lists (Caul, 1999; Matland, 2005; Norris, 1996; Paxton and Kunovich, 2003; Schmidt, 2008; Thames and Williams, 2010; Valdini, 2012), although the evidence is not unequivocal (McElroy and Marsh, 2010; Shugart, 1994; Taagepera, 1994). Ballot structure should be influential since the decision to elect women is either in the hands of voters - in the case of open lists - or of party gatekeepers who-in the case of closed lists - hold the decision to place women on lists in prominent positions. Consequently, we could expect parties to face different sets of considerations when selecting candidates under different ballot structures, and by extension, raise or lower the barriers for women's representation in the EP.

The EU-27 also diverge on average district magnitude, a feature considered to be one of the key explanatory factors accounting for levels of women's representation in advanced industrialized democracies (Salmond, 2006). District magnitude directly impacts party decision-making with regard to candidate nominations by framing how candidates are selected. In a nutshell, a PR system that allocates two or more seats per district will lead to more diversity in a legislature than systems in which there is a single member elected per district (Norris, 2004). The higher the amount of seats per district, the greater the opportunities and incentives parties face to balance their tickets with female candidates. Higher district magnitude is theorized to boost incentives for parties to engage in ticket-balancing to reach the broadest potential spectrum of voters and, by extension, leads to more egalitarian nominations (Darcy et al., 1994; Kenworthy and Malami, 1999; Matland, 1993; Salmond, 2006; Schwindt-Bayer and Mishler, 2005). In addition, voters also react 
to district magnitude: "voters who might be more hesitant to vote for a woman as their only representative may be more willing to vote for a woman as one of many candidates' (Matland, 1993: 739). We could thus expect that higher district magnitudes in EP elections will lead to higher percentages of women elected.

The size of districts to elect MEPs varies significantly among the EU-27: district magnitude ranges from 3 to 99 with an average of 18.84 in the 2004 elections and 19.45 in the 2009 elections (displayed in Figure 3). To provide a measure of comparison, the average district magnitude for lower house elections across the EU-27 was 20.21 in 2004, and 21.42 in 2009 , and ranged from 1 to 150 . The variability of average district magnitudes is therefore almost as large between the two levels of elections as it is across countries for national elections, despite EP elections all being held under PR rules. Such large differences in district magnitude should allow us to substantiate the claim that women fare better in larger districts in EP elections than in national legislative bodies.

Variations in the effective threshold of a district, that is the average threshold for achieving representation in a district (Taagepera, 1998), are also considerable when contrasting the national rules for electing MEPs. The variation in the vote percentage a party must obtain to be granted a seat follows the distributions displayed in Figure 3 . The effective threshold thus provides a substantive measure of how permissive an electoral system is. ${ }^{4}$ In national elections, the average effective threshold

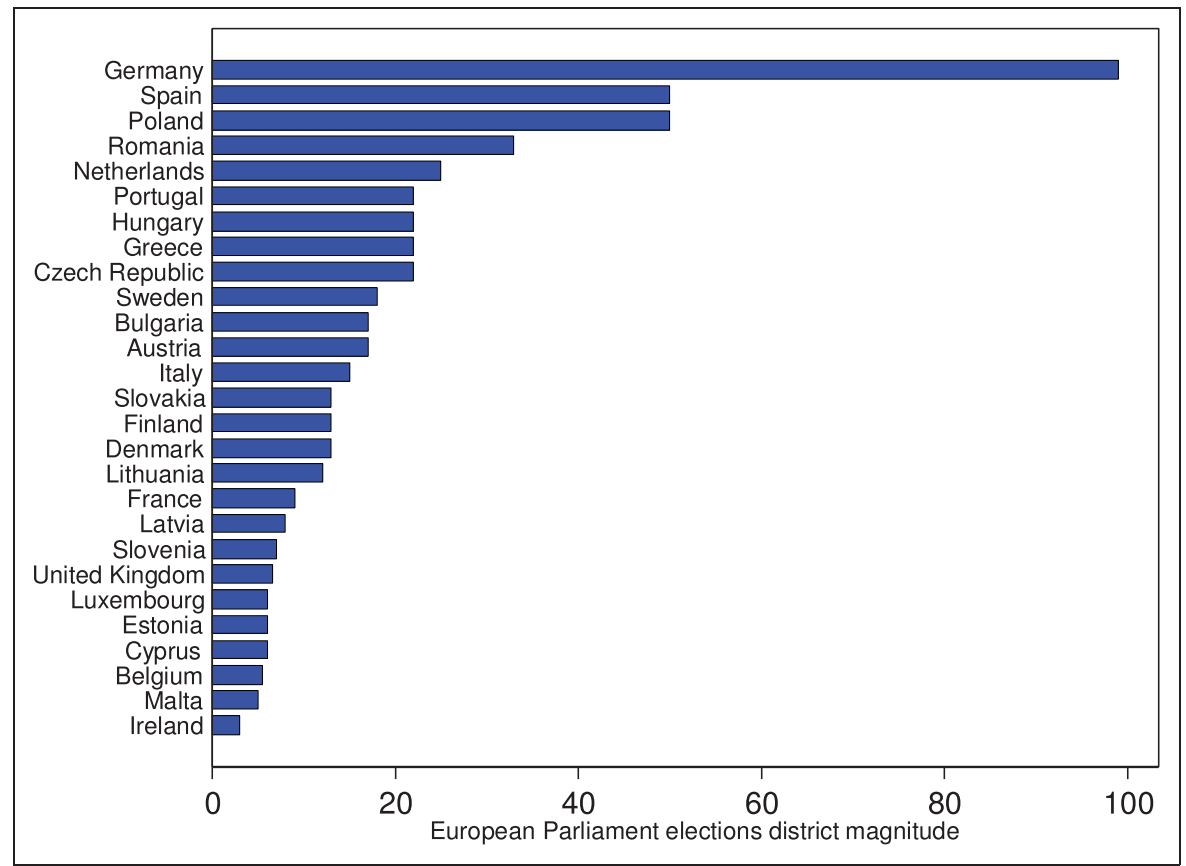

Figure 3. District magnitude among EU-27 countries for the 2009 EP election. 
is close to $11 \%$ across the EU-27, and varies from 0.50 to $37 \%$. In EP elections, the average threshold is close to $7 \%$ and varies from 0.75 to about $19 \%$. Although the effective threshold is on average a few percentage points lower in EP elections, there is still a large amount of variation in the implicit thresholds between the 27 EU member states. Generally, we expect lower effective thresholds to be associated with high proportions of women elected.

One important caveat has to be kept in mind: the ceiling on district magnitude is tied to the number of electable MEPs per country, ranging from 5 in Malta to 99 in Germany. Electoral formulas, district magnitude, and the number of MEPs each country elects have significant consequences for the resulting proportionality of seat attribution (Katz, 1997; Lijphart, 1986): proportionality is constrained in the case of countries having only a handful of seats to fill. Differences in levels of disproportionality calculated according to Gallagher $(1991)^{5}$ are illustrated in Figure 4 for the 2009 EP elections. Despite the use of PR in all countries, we observe a large variability in how elections have functioned in reality. On average, EP elections have displayed higher levels of disproportionality (Least-square index 7.08) than national parliamentary elections, although two countries (France and the UK) employ majoritarian rules for their lower houses (Least-square index 5.59). ${ }^{6}$ Even though all countries employ PR, seats in the EP have not

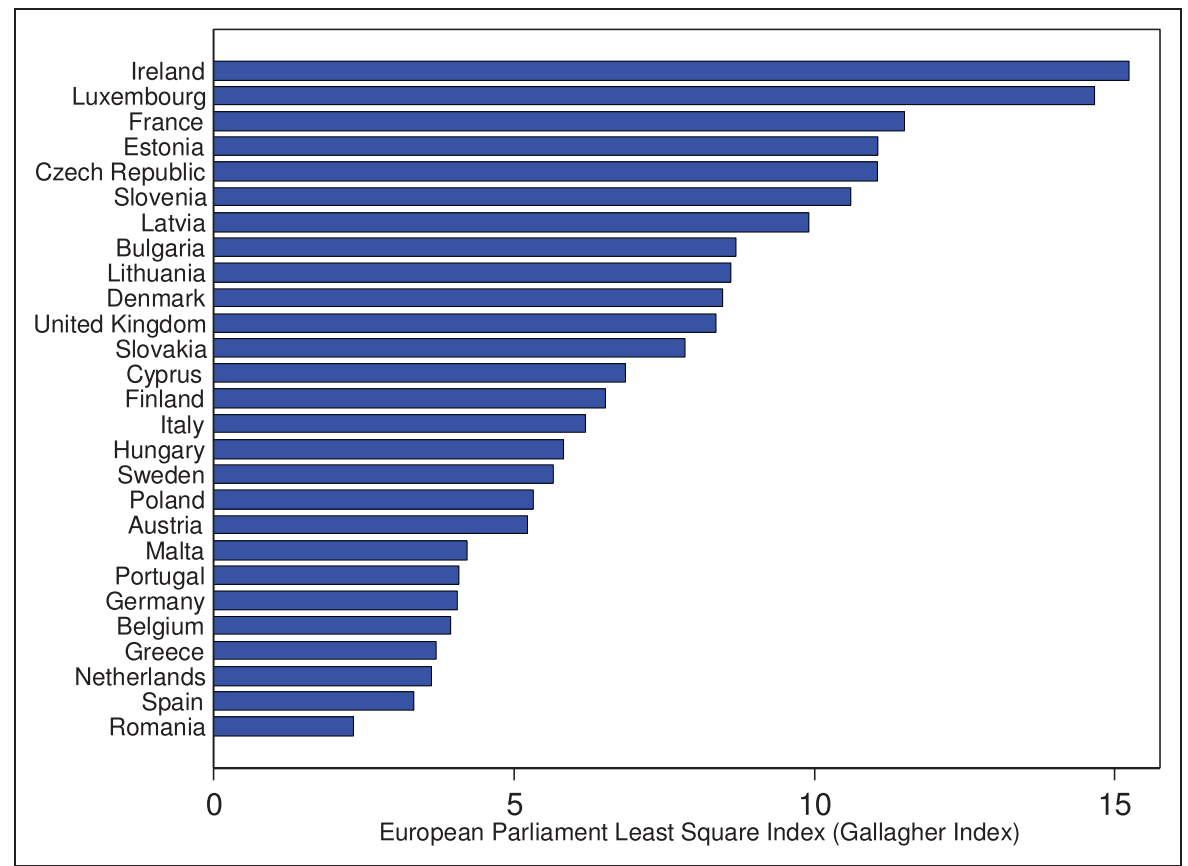

Figure 4. Disproportionality among the EU-27 for the 2009 EP election. 
been allotted more proportionally than in national parliaments: in 2009, only in seven countries were EP elections less disproportional than their respective national election (France, Greece, Lithuania, Portugal, Romania, Spain, and the UK).

These findings as well as the large variation we find in subtypes of electoral institutions allow us to question the claim that the use of PR is the reason why women have been more successful in gaining representation in the aggregate in the EP. In the following section, we test whether the considerable variation within types of PR systems in terms of specific features of electoral design (subtypes of electoral formulas to transfer votes into seats, the average size of the district magnitude, effective thresholds, ballot structures, and the proportionality of the distribution between votes and seats) is linked to the electoral success of women in the EP.

\section{Measures and empirical strategy}

In order to test the influence of electoral institutions on the descriptive representation of women in the EP on the one hand, and to account for the difference in representation between national lower houses and EP on the other hand, we proceed in three steps. Given the small number of observations due to the number of EU member states, we employ data from the 2004 and 2009 EP elections (with 25 and 27 member states respectively) separately in order to reduce the risk of type I errors attributable to pooling (pooling cases across years would present important estimation difficulties since the number of cases fluctuates over time and would lead to unbalanced panels). In the first step, we present a series of bivariate correlations to examine the relationship between specific features of electoral institutions of national lower houses and the EP with the proportion of women represented in the legislatures at each level. Second, we present regression analyses estimating the percentage of women in the EP integrating control variables suggested by previous research. These two steps allow us to test whether the conventional wisdom derived from scholarship on national lower houses concerning the effect of electoral rules can be transferred to the EP. In the third step, we estimate a series of models examining the difference in features of electoral rules between lower houses and EP elections on the difference between the proportion of women represented in the lower houses and in the EP. In this step, comparing national and EP levels of representation allows us to circumvent some of the shortcomings of existing studies of women's representation, namely the issue of whether institutions are the causes or outcomes of party systems and political traditions (Roberts et al., 2013). In contrast with national electoral rules, which are often considered to be consequences of party systems rather than causes (Colomer, 2005; Grumm, 1958; Lipson, 1964; Matland, 1998; Rokkan, 1970), EU electoral rules can be considered 'exogenous' because they were mainly imposed: the Council's decision of 2002 was to enforce uniform electoral rules corresponding to the family of PR, leaving the member states with some discretion to adapt PR to domestic circumstances. Comparing the EU with national settings should thus yield the raw influence of 
electoral rules on representation minus the endogenous part estimated for national models. In other words, there is less risk of overestimating the causal effects of electoral rules since the direction of the causal relationship is more clear-cut in the case of studying the effects of electoral rules on women's representation in the EP. Moreover, since electoral rules have been found to operate differently under certain conditions (e.g. developing countries, emerging democracies) (Inglehart and Norris, 2003; Matland, 1998; Moser, 2001; Moser and Scheiner, 2012; Oakes and Almquist, 1993), comparing representation in national parliaments and the EP allows us to keep national attitudinal circumstances constant. Given that candidates for both parliaments, national and European, are drafted from the same population and elected by the same electorate, a comparison of women's presence in national parliaments and in the EP allows us to control for a large number of explanatory factors for representation based on socioeconomic and cultural influences since these affect the electorates irrespective of the jurisdictional level at which elections take place.

We operationalize our dependent and independent variables as follows. For the dependent variables, we use (1) the percentage of women represented in lower houses of EU member states, (2) the percentage of women elected in the EP, as well as (3) the difference between these two figures. Turning to our independent variables, we use four indicators to capture the effects of electoral institutions. We use the Gallagher's least square index of disproportionality, the logarithm of district magnitude, effective thresholds, and ballot structures (closed, ordered, open). Aside from electoral rules, the other potentially relevant factors discussed in the literature to address the observed variations in female representation are included as control variables. Note that we deliberately set aside the important discussion about the roles of gender quotas. While research shows the importance of the implementation of such measures for the representation of women (Krook, 2009; Murray, 2010), findings for the 27 EU member states are in direct opposition with established research: countries with the highest proportion of women represented in national parliaments are those where there are no quotas. These cases pull results in a way that makes it impossible to use indicators representing quotas in this selection of countries.

\section{Percentage of women in national lower houses}

Norris and Franklin (1997) hypothesized that patterns of recruitment for the EP are affected by the same systematic patterns at the national level. Since nominations are made by national parties, the same group of gatekeepers is responsible for nominations at both levels. Another reason to control for the level of representation at the national level is the possibility of contagion effects. A high presence of women in the executive is said to trigger a dynamic of increasing returns, whereby successful women reach out to recruit more women as they attain better positions (Caul Kittilson, 2006; Kunovich and Paxton, 2005). The out-group effect is reduced when women-in-office are a sufficiently large group (Niven, 1998). 
Moreover, psychological bias on the part of (male) gatekeepers can play a substantial role in candidate nominations in the absence of quotas (Mezey, 1980; Niven, 1998; Studlar and McAllister, 1991). Therefore, we expect that the higher the level of women represented in legislatures at the domestic level, the smaller the gap between the national and the EU level of representation.

\section{Macro-societal factors}

Macro-level factors that underpin the level of women's political representation, such as levels of education, the presence of women in the workforce (Iversen and Rosenbluth, 2008; Mateo Diaz, 2005; Rosenbluth and Salmond, 2006; Rule, 1987; Siaroff, 2000), timing of enfranchisement (Mateo Diaz, 2005), the importance of religion and types of religious affiliations (Inglehart and Norris, 2003; Mateo Diaz, 2005; Welch and Studlar, 1986), stereotypes and widely shared ideas about gender roles (Dahlerup, 2006) in each country should help us to explain cross-country differences in women's representation. Yet, they should not have a differential impact on the recruitment processes and electability of women at the domestic and the EU-level. To capture the social context in which an election occurs, we use the percentage of women in the labor force (World Bank). This indicator will encapsulate the degree to which countries adhere to traditional gender roles: previous studies have shown that women's entry in the labor force is associated with a decline in support for traditional gender roles (Andersen, 1975; Andersen and Cook, 1985).

\section{Parties (orientation)}

Given the role of political parties as gatekeepers for political office, the orientation of political parties on the two most salient dimensions of European politics, the left-right as well as the European integration vs. national sovereignty dimension (Manow and Döring, 2008; Marks and Steenbergen, 2002; McElroy and Benoit, 2007) also has a potential impact on the proportion of women elected. A large body of literature suggests that parties on the left, both at the national and EP-level, are more likely to support women as candidates than parties on the right (Beckwith, 1992; Caul, 1999; Freedman, 2002; Hix and Lord, 1997; Krook, 2010; Mather, 2001; Matland, 1993; Matland and Studlar, 1996; Norris and Franklin, 1997; Vallance and Davis, 1986). Moreover, it is argued that PR increases the likelihood of left-leaning parties to be elected (Iversen and Soskice, 2006). Party positioning on European integration may as well play a role; Chiva (forthcoming) suggests that Eurosceptic parties are more reluctant to recruit women in eastern European countries, an assertion that could also apply to the remaining members of the EU. To measure political parties' positions on these two issue dimensions, we have calculated weighted averages based on each political parties' share of seats on both dimensions from the Chapel Hill Expert Survey (Bakker et al., forthcoming). 


\section{Salience}

Taking into account the hypothesis of lower salience of EP elections, we might expect the law of minority attrition to apply: 'The more important levels have fewer positions, and the share of minorities goes down. The law of minority attrition is a quantitatively predictive logical model that expresses it more precisely. A party with a small share of seats gets an even smaller share of seats, and the precise figure depends on assembly size and the total number of voters. The law of minority attrition might also help determine which part of the 'rubber ceiling' on women's advancement is natural and which part is socially imposed' (Taagepera, 2007: 204). Furthermore, if there are differences in the perceived importance of EU elections across countries, as suggested by Flickinger and Studlar (2007), we might also expect differences on the supply side and in the barriers to entry. In the following we use differences in voting turnout rates to assess the relative 'salience' of an election. ${ }^{7}$ We expect that large differences in turnout rates between national and EP elections should be symptomatic of low salience (of EP elections in relation to national elections) and be associated with larger proportions of women elected.

\section{Analyses and discussion}

This section presents the results of our analyses on the impact of electoral rules and control variables on the representation of women in the EP and on the differences in female representation between national legislatures and the EP. In a first step, we compare the most common explanations driving descriptive representation. Table 1 displays a series of bivariate correlations between individual features of electoral systems (the level of disproportionality, district magnitude, effective thresholds, and the structure of ballots) as well as socioeconomic factors on the percentage of women in lower houses and in the EP. We test the relationship between electoral rules and the proportion of women represented in national lower houses in 2004 and 2009 (to allow for a direct comparison with the EP elections). The results replicate the findings, which have been broadly disseminated in the literature (see the first two columns in Table 1). Coefficients are statistically significant, despite the small number of cases and the fact that we know these features to be less effective in explaining some of the variance in East Central European countries and Malta (Fortin, 2008; Lane, 1995; Moser and Scheiner, 2012).

When we turn to exploring the impact of electoral rules on the representation of women in the EP, we obtain a very different picture (see the last two columns in Table 1). It appears that the overall level of proportionality of the elections has no statistically significant effect on the proportion of women elected. While the correlation coefficients point in the right direction, neither district magnitude nor effective thresholds are linked to the proportion of female MEPs elected in both 2004 and 2009 elections. Ballot structures also fail to make a statistically significant impact on the dependent variables. The types of ballots - closed, ordered, or open-do not have a significantly different effect from one another. Contextual 
Table I. Bivariate correlations between individual features of electoral rules and percent women in national lower houses and the EP in 2004 and 2009.

\begin{tabular}{|c|c|c|c|c|}
\hline & Percent women & Percent women & Percent women & Percent women \\
\hline & Lower & Lower & EP & EP \\
\hline & Houses & Houses & & \\
\hline & 2004 & 2009 & 2004 & 2009 \\
\hline \multicolumn{5}{|l|}{ Electoral rules } \\
\hline Index of disproportionality & $-0.39 * *$ & $-0.33^{\mathrm{a} *}$ & -0.14 & -0.14 \\
\hline District magnitude (log) & $0.41 * *$ & $0.30^{\mathrm{b}}$ & 0.23 & 0.18 \\
\hline Effective threshold & $-0.38 *$ & $-0.34 * *$ & -0.29 & -0.30 \\
\hline \multicolumn{5}{|l|}{ Ballot structure ${ }^{c}$} \\
\hline Closed (vs. all others) & & & -0.18 & 0.02 \\
\hline Flexible (vs. all others) & & & 0.12 & 0.26 \\
\hline Open (vs. all others) & & & 0.06 & -0.30 \\
\hline \multicolumn{5}{|l|}{ Socioeconomic factors } \\
\hline Women in labor force (\%) & $0.53^{* * * *}$ & $0.56^{* * * *}$ & $0.42 * *$ & $0.66 * * *$ \\
\hline
\end{tabular}

Note: Cell entries represent Pearson's $r$ correlation coefficients between the percent women in national lower houses and European Parliament and individual features of electoral laws for each level. In the case of ballot structure, the measure of association used is Spearman's $\rho$.

aMalta removed (extreme outlier).

${ }^{\mathrm{b}} p=0.125$.

'Ballot structure omitted for lower house elections due to limited amount of cases of pure forms of proportional representation, hence direct comparability with EP elections.

$* p<0.10$,

$* * p<0.05$,

$* * * 0<0.01$.

factors therefore remain the most stable explanatory variables for the percentage of women elected to the EP, irrespective of the controls included in the analyses. The socioeconomic context, measured as the percentage of women active in the labor force, achieves similar effects on the percentage of women in national lower houses and the EP in both 2004 and 2009. This result tells us that, unsurprisingly, macrosocioeconomic structures operate similarly at both levels. Our preliminary results therefore suggest that researchers might have been too hasty in crediting the type of electoral rules employed to elect MEPs for the high proportion of women in the EP.

In fact, upon closer visual inspection of the differences in descriptive representation between both levels presented in Figure 5, we observe no obvious effect of types of electoral rules when considered as general families of formulas - e.g. majoritarian, mixed, and proportional - on the distribution of cases. We observe a U-shaped relationship between the proportion of women in lower houses and the magnitude of the difference in representation between lower houses and the EP. The countries in which women are the least represented are those in which the 


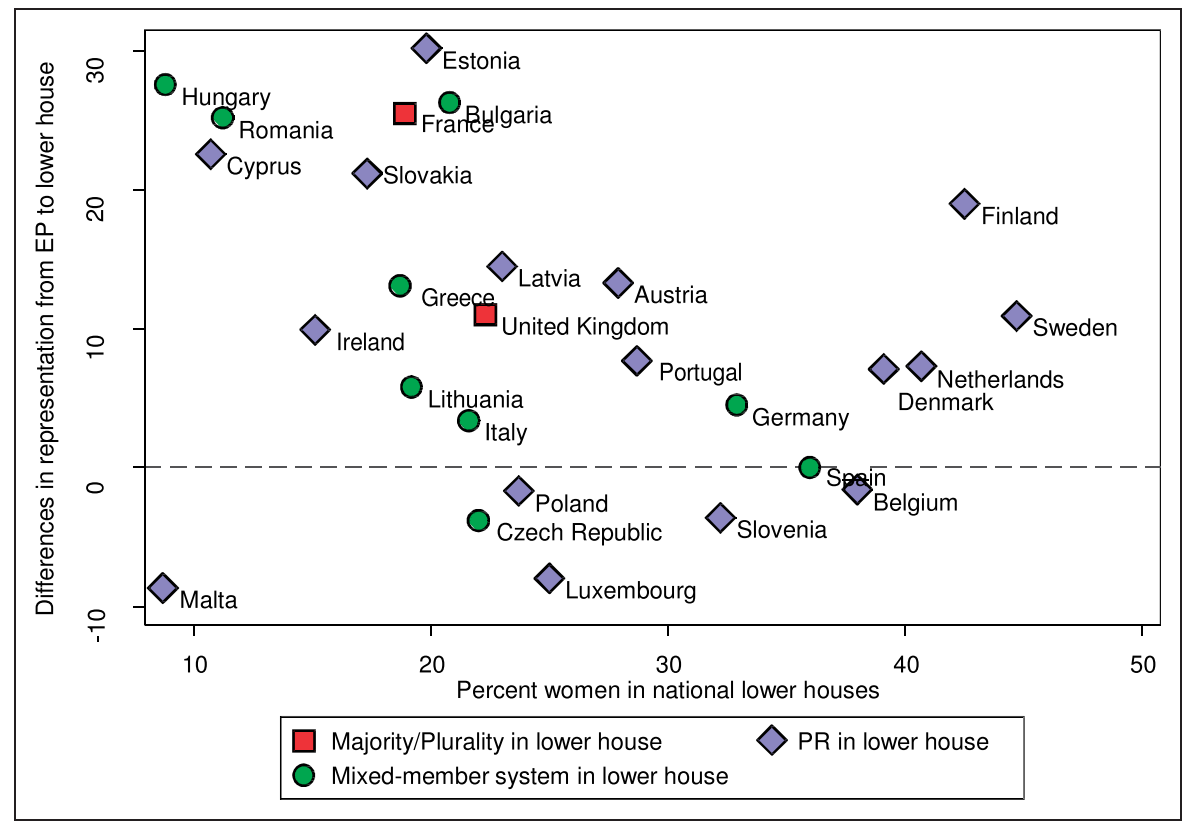

Figure 5. National-EP gender gap: percent women in EP minus percent women in Lower Houses (2009).

differences with the proportion of women represented in the EP are the most pronounced, with the exception of Malta. ${ }^{8}$ This tendency reverses once the representation of women reaches about $25 \%$ in lower houses, reflecting existing scholarship on Scandinavian countries (Kenworthy and Malami, 1999; Matland, 1993; Siaroff, 2000). We thus do not find supporting evidence for Vallance and Davis' (1986) claim that countries with two different electoral systems for domestic legislatures and the EP explain differences in levels of representation. The cluster of cases that display the largest difference between both levels is not only composed of countries that employ different rules at both levels: Estonia, Cyprus, Slovakia and Finland employ similar forms of PR in both national and EP elections. Bulgaria, Hungary and Romania use mixed-member proportional (MMP) rules, commonly considered to produce proportional outcomes in the literature (Bawn and Thies, 2003). Far from what Vallance and Davis (1986) argue about the use of different electoral systems leading to larger differences in women's representation, the only pure majoritarian system in the cluster of countries with large differences between levels is France. We can therefore not attribute the higher proportion of women in the EP to differences in electoral formulas between national parliamentary elections and the EP.

What, then, explains the proportion of women represented in the EP? Table 2 presents a series of models seeking to account for the percentage of women MEPs in 2009. Model 1 is a baseline model with the percentage of women in the labor 
Table 2. OLS regressions explaining the percentage of women in the EP in 2009.

\begin{tabular}{lcccc}
\hline & Model I & Model 2 & Model 3 & Model 4 \\
\hline \% women in labor force & $1.042^{* * * *}$ & $0.622^{* * *}$ & $0.695^{* *}$ & $0.722^{* *}$ \\
& $(0.296)$ & $(0.278)$ & $(0.308)$ & $(0.322)$ \\
\% women in lower house & & $-1.96 I^{* *}$ & $-2.185^{* * *}$ & $-2.086^{* * *}$ \\
& & $(0.761)$ & $(0.626)$ & $(0.676)$ \\
Quadratic term of \% women & & $0.042^{* * *}$ & $0.045^{* * *}$ & $0.043^{* * *}$ \\
in lower house & $(0.193)$ & $(0.012)$ & $(0.012)$ \\
Parties average left-right & & -0.982 & \\
& & & $(3.553)$ & \\
Parties average EU position & & & & 1.022 \\
& & & 28.96 & $(3.214)$ \\
Constant & $-17.25^{* * *}$ & $22.47^{*}$ & 24 & 15.70 \\
Cases & $26^{\mathrm{a}}$ & $26^{\mathrm{a}}$ & 0.000 & 0.000 \\
Prob $>\mathrm{F}$ & 0.002 & 0.000 & 0.000 \\
Adj- $\mathrm{R}^{2}$ & 0.238 & 0.404 & 0.396 & 0.398 \\
\hline
\end{tabular}

Note: Cell entries represent OLS regression coefficients with jackknife standard errors in brackets.

${ }^{a}$ Extreme outlier, Malta removed (extreme outlier).

$* p<0.10$

$* * p<0.05$,

$* * * p<0.01$.

force, Model 2 adds the percentage of women in the lower house and a quadratic term to model the nonlinear component of the relationship displayed by this variable (cf. the U-shaped relationship in Figure 5), while Models 3 and 4 introduce party positions. The baseline model, using the percentage of women in the labor force, provides a moderate fit with the data, with close to $24 \%$ explained linear variance. Adding the percentage of women in lower houses and a quadratic term increase explained linear variance to $40 \%$. Including political parties' orientation in Models 3 and 4 does not make a statistically significant impact on the percentage of women represented in the EP. ${ }^{9}$ All things being equal, it seems that neither the proportion of left parties nor Europhile parties is linked to higher proportions of women MEPs.

Next, we seek to explain the differences between the levels of descriptive representation in national parliaments vs. the EP (cf. Table 3), using the difference of the percentages between both levels as a dependent variable, measured in 2009. ${ }^{10}$ Model 5 presents a summary of the nonlinear relationship shown in Figure 5, using the percentage of women in the lower house and integrating a quadratic term of this variable to accommodate the curvature in the relationship. Models 6-8 add the differences of a series of features of the electoral systems between the EP and lower houses: disproportionality, district magnitudes, and effective thresholds. Model 9 integrates the difference in levels of turnout between national and EP 
Table 3. OLS regressions explaining the differences between EP and lower houses in 2009.

\begin{tabular}{|c|c|c|c|c|c|}
\hline & Model 5 & Model 6 & Model 7 & Model 8 & Model 9 \\
\hline$\%$ women in lower house & $\begin{array}{c}-3.057^{* * * *} \\
(0.705)\end{array}$ & $\begin{array}{c}-3.097 * * * \\
(0.735)\end{array}$ & $\begin{array}{c}-3.094 * * * \\
(0.744)\end{array}$ & $\begin{array}{c}-3.023 * * * * \\
(0.74 I)\end{array}$ & $\begin{array}{c}-3.045^{* * * *} \\
(0.758)\end{array}$ \\
\hline $\begin{array}{l}\text { Quadratic term of } \% \\
\text { women in lower house }\end{array}$ & $\begin{array}{l}0.047^{* * *} \\
(0.014)\end{array}$ & $\begin{array}{l}0.048 * * * \\
(0.015)\end{array}$ & $\begin{array}{l}0.048 * * * \\
(0.014)\end{array}$ & $\begin{array}{l}0.05 I^{* * * *} \\
(0.014)\end{array}$ & $\begin{array}{c}0.047^{* * * *} \\
(0.015)\end{array}$ \\
\hline \multicolumn{6}{|l|}{ Differences from EP to $L H$ : } \\
\hline Disproportionality & & $\begin{array}{l}-0.320 \\
(0.428)\end{array}$ & & & \\
\hline District Magnitude & & & $\begin{array}{l}0.609 \\
(1.634)\end{array}$ & & \\
\hline Effective threshold & & & & $\begin{array}{l}-0.289 \\
(0.201)\end{array}$ & \\
\hline Levels of turnout (VAP) & & & & & $\begin{array}{l}-0.057 \\
(0.187)\end{array}$ \\
\hline Constant & $53.61 * * *$ & $54.66 * * *$ & $53.95 * * *$ & $54.70 * * *$ & $52.50 * * *$ \\
\hline Cases & 26 & 26 & 26 & 26 & 26 \\
\hline Prob $>F$ & 0.000 & 0.000 & 0.000 & 0.000 & 0.000 \\
\hline $\operatorname{Adj}-R^{2}$ & 0.351 & 0.341 & 0.325 & 0.382 & 0.326 \\
\hline
\end{tabular}

Note: Cellentries represent OLS regression coefficients with jackknife standard errors in brackets. Extreme outlier, Malta, omitted from analyses.

$*_{p}<0.10$,

$* * p<0.05$,

$* * * p<0.01$.

elections to verify whether differences between levels of salience between the two types of elections is linked to the difference in descriptive representation. The only variables that attain a statistically significant effect on the dependent variable are the level of female representation in the respective lower house and its quadratic term. This further shows that patterns of recruitment for the EP are largely affected by the same systematic patterns that operate at the national level, despite the existence of different sets of electoral rules. This finding is not unexpected, since the same group of gatekeepers is responsible for nominations at both levels, although we can hypothesize that the nomination process is more centralized for EP elections given the smaller amount of electoral districts. In other words, our results indicate that none of the features of electoral and party systems, which are understood to have an effect on descriptive representation in domestic politics, make an impact in EP elections. The difference in disproportionality, in district magnitude, and effective thresholds between EP elections and national elections are not linked to the difference in levels of women's representation between both levels. Differences or similarities of the electoral rules between the two types of elections in 
each country therefore do not have a systematic impact on descriptive representation, nor does the difference in salience between elections.

In light of the broad literature on the effects of electoral rules on representation, our results seem perplexing at first. Yet, they appear less puzzling when considering the argument that it is quite possible that countries self-selected into [electoral systems] on the basis of cultural traits and historical experience, which also shape long-run collective preferences and thus influence policy and performance even today' (Persson and Tabellini, 2003: 114). In other words, electoral rules can be seen as outcomes of party systems and cleavage structures prevalent in particular societies rather than their cause (Colomer, 2005; Grumm, 1958; Lipson, 1964; Matland, 1998; Roberts et al., 2013; Rokkan, 1970). The EP and its electoral arena are different from the national arenas in this regard (Bartolini, 2005): the set of rules governing EP elections was imposed. The adoption of PR-rules for EP elections stems from the desire of political elites to make electoral procedures more uniform and to increase the transparency and democratic legitimacy of EP elections. EP electoral rules are therefore not based on national cleavage structures. If we consider the main cleavages to be located at the country level, and still being a driving force in how citizens cast their votes, our findings make a lot of sense. Our results also provide additional evidence for Roberts et al.'s (2013) hypothesis that descriptive representation does not hinge so much on electoral rules when the issue of endogeneity of institution is accounted for. This would explain why features of electoral systems are linked to descriptive representation in lower houses, but not for the EP as displayed in Table 1.

Still, there is a large part of variance that is non-attributable to the factors discussed here. For instance, most countries have very different districting in national compared to EP elections (with the exception of Luxembourg and Slovakia). EP election districts are therefore not territorial entities backed by local party organizations, unlike in national elections where the effects of geographic connection are highly important. In most countries where the EP elections are run in one nationwide district rather than in various regional districts, the power of national party offices is reinforced. This, in turn, begets different dynamics underpinning candidate selection, e.g. how to address intra-party concerns about territorial and ideological balance on the lists or how to distribute list positions among old and new personnel. Such differences in candidate selection procedures undoubtedly have an impact on how gender-balanced lists are.

\section{Conclusions}

Existing research on descriptive representation suggests that a combination of macro factors provides the strongest explanation for the proportion of women elected to national parliaments. Most scholars support the thesis that gender inequality in elected office is mainly attributed to the workings of electoral rules, but also to factors such as the ideological orientation of political parties, the 
cultural orientation of societies, socioeconomic factors, the role of women in society, and the timing of women's enfranchisement. In this paper, we asked how these factors perform at the EU level. Is the larger proportion of women in the EP attributable to the use of particular electoral rules-PR with large district magnitude - as the literature on descriptive representation would have us expect? Much of what we know about women's representation in the EP is based on assumptions about the uniformity of electoral rules, namely the use of PR. But in reality, despite the effort to harmonize the electoral rules for EP elections, elections in the 27 EU member states are not entirely uniform: they still exhibit important differences in the levels of disproportionality, the magnitude of districts, effective thresholds, and ballot structures. Given what we know about the impact of electoral institutional design on the composition of parliaments in individual countries, we would have expected that these features affect the proportion of women in the EP.

Our evidence suggests that electoral rules have only very limited impact on descriptive representation in the EP, in stark contrast to what can be observed in the composition of lower houses. Contextual factors related to national characteristics are clearly more powerful factors in explaining the patterns of descriptive representation in the EP: '[...] party systems are still largely determined nationally (e.g. Lipset and Rokkan, 1967) and therefore there is limited scope for influence here by EP electoral system design' (Farrell and Scully, 2005: 86). Our findings thus raise the question as to how consequential institutional design - the choice of electoral rules - is on shaping the composition of the EP. In our case, representation does not causally depend on electoral rules but is attributable to 'the fact that women's representation and electoral rules [at the national level] are jointly determined' (Roberts et al., 2013: 1556). In other words, electoral rules result from cleavage structures and the structure of party systems in national contexts. By contrast, electoral rules are imposed in the EU, so comparing national and EU elections yields the raw influence of rules on representation, minus the endogenous part estimated in national models. Once examined as exogenous, such as in the EP context, their hypothesized effects vanish. The effects of electoral rules are therefore context dependent (Amorim Neto and Cox, 1997; Boix, 1999; Matland, 1998; Moser and Scheiner, 2012; Odershook and Shvetsova, 1994), and the context of EP elections is different from that of national elections. Either way, our results suggest that we should not take for granted that the effect of electoral institutions on descriptive representation applies the same way at the national and the EU level.

\section{Acknowledgements}

The authors wish to thank three anonymous referees for their helpful comments and Hermann Schmitt for guidance and encouragement. Verena Simmel and Katharina Wedekind provided valuable research assistance in the preparation for this article. Jessica Fortin-Rittberger thanks GESIS - Leibniz Institut für Sozialwissenschaft for an excellent research infrastructure. 


\section{Notes}

1. In 2004, Belgium, Cyprus, Denmark, Finland, Germany, Malta, and Poland all had a higher proportion of women in their lower houses than in the EP. In 1999, Italy, Luxembourg, the Netherlands, and Portugal had higher proportions of female MPs than MEPs.

2. The literature in this regard is sparse: Chiva (forthcoming) investigates differences in women's representation among six East European countries, while an article by Norris and Franklin (1997) investigates the differences observed in 1994 using a survey conducted amongst candidates and incumbents to the EP in 1994 (12 countries). Beauvallet and Michon (2008) examine the case of France.

3. One notable change in electoral formula is the UK in 1999, which abandoned first-pastthe-post for the EP elections. Elections prior to 2004, with the UK as exception, were conducted under rather similar procedures.

4. The effective threshold is calculated in the following way: $E=75 \% /(\mathrm{m}+1)$, where $\mathrm{m}$ represents district magnitude. Effective thresholds are implicit thresholds since they are different than those legally mandated thresholds on representation. These represent 'the minimum vote share a party needs to win a seat under the most favorable conditions, and the maximum vote share at which a party still could fail to do so under the worst conditions' (Taagepera, 1998: 395).

5. Gallagher's least squares index measures the disparity between vote shares and seat shares according to the following formula:

$$
\mathrm{LSq}=\sqrt{\frac{1}{2}} \sum_{\mathrm{i}=1}^{\mathrm{n}}\left(\mathrm{V}_{\mathrm{i}}-\mathrm{S}_{\mathrm{i}}\right)^{2}
$$

6. Figures are for 2004 and 2009 combined.

7. Turnout figures are from IDEA international.

8. Malta uses the STV, which is considered a form of proportional representation.

9. Neither the left-right orientation nor the EU orientation of parties gaining representation in the EP has a statistically significant impact on the percentage of women MEPs, even when no control variables are included in the model or when the three biggest outliers are omitted from the analyses.

10. The same series of models was performed for the year 2004 and yielded almost exactly the same results.

\section{References}

Amorim Neto O and Cox G (1997) Electoral institutions, cleavage structures, and the number of parties. American Journal of Political Science 41(1): 149-174.

Andersen K (1975) Working women and political participation, 1952-1972. American Journal of Political Science 19(3): 439-455.

Andersen K and Cook EA (1985) Women, work, and political attitudes. American Journal of Political Science 29(3): 606-625.

Bakker R, de Vries C, Edwards E, et al. (forthcoming) Measuring party positions in Europe: The Chapel Hill Expert Survey Trend File, 1999-2010. Party Politics. Epub ahead of print 29 November 2012. DOI: 10.1177/1354068812462931. 
Bartolini S (2005) Restructuring Europe: Centre Formation, System Building, and Political Structuring between the Nation State and the European Union. Oxford: Oxford University Press.

Bawn K and Thies MF (2003) A comparative theory of electoral incentives representing the unorganized under PR, plurality and mixed-member electoral systems. Journal of Theoretical Politics 15(1): 5-32.

Beauvallet W and Michon S (2008) Les femmes au Parlement européen: Effets du mode de scrutin, des stratégies et des ressources politiques. L'exemple de la délégation française. Swiss Political Science Review 14(4): 663-690.

Beckwith K (1992) Comparative research and electoral systems: Lessons from France and Italy. Women and Politics 12(1): 1-33.

Boix C (1999) Setting the rules of the game: The choice of electoral systems in advanced democracies. American Political Science Review 93(3): 609-624.

Bowler S and Farrell DM (1993) Legislator shirking and voter monitoring: Impacts of European Parliament electoral systems upon legislator-voter relationships. Journal of Common Market Studies 31(1): 45-70.

Carey JM and Shugart MS (1995) Incentives to cultivate a personal vote: A rank ordering of electoral formulas. Electoral Studies 14(4): 417-439.

Castles FG (1981) Female legislative representation and the electoral system. Politics 1(2): 21-27.

Caul M (1997) Women's Representation in National Legislatures: Explaining Differences across Advanced Industrial Democracies. Paper presented at the western political science association meeting. Tucson/AZ.

Caul M (1999) Women's representation in parliament: The role of political parties. Party Politics 5(1): 79-98.

Caul Kittilson M (2006) Challenging Parties, Changing Parliaments: Women and Elected Office in Contemporary Western Europe. Columbus, OH: Ohio State University Press.

Chiva C (forthcoming) Gender, European integration and candidate recruitment: The European Parliament elections in the new EU member states. Parliamentary Affairs. Epub ahead of print 30 August 2012. DOI: 10.1093/pa/gss047.

Colomer JM (2005) It's the parties that choose electoral systems (or Duverger's law upside down). Political Studies 53(1): 1-21.

Dahlerup D (2006) Women, Quotas and Politics. London: Routledge.

Darcy R, Welch S and Clark J (1994) Women, Elections and Representation. Lincoln: University of Nebraska Press.

Duverger M (1955) The Political Role of Women. Paris: The United Nations Economic and Social Council.

Farrell DM and Scully R (2005) Electing the European Parliament: How uniform are 'uniform' electoral systems? Journal of Common Market Studies 43(5): 969-984.

Farrell DM and Scully R (2007) Representing Europe's Citizens: Electoral Institutions and the Failure of Parliamentary Representation. Oxford: Oxford University Press.

Flickinger RS and Studlar DT (2007) One Europe, many electorates? Models of turnout in European Parliament elections after 2004. Comparative Political Studies 40(4): 383-404.

Footitt H (2002) Women, Europe and the New Language of Politics. London and New York: Continuum. 
Fortin J (2008) Patterns of democracy? Counterevidence from nineteen post-communist countries. Zeitschrift für Vergleichende Politikwissenschaft 2(1): 198-220.

Freedman J (2002) Women in the European Parliament. Parliamentary Affairs 55(1): 179-188.

Gallagher M (1991) Proportionality, disproportionality and electoral systems. Electoral Studies 10(1): 33-51.

Gallagher M (1992) Comparing proportional representation electoral systems: Quotas, thresholds, paradoxes and majorities. British Journal of Political Science 22(4): 469-496.

Grumm JG (1958) Theories of electoral systems. Midwest Journal of Political Science 2(4): $357-376$.

Héritier A (2007) Explaining Institutional Change in Europe. Oxford: Oxford University Press.

Hix S and Hagemann S (2008) Could changing the electoral rules fix European Parliament elections? Politique Européenne 2(28): 37-52.

Hix S and Høyland B (2013) Empowerment of the European Parliament. Annual Review of Political Science 16: 171-189.

Hix S and Lord C (1997) Political Parties in the European Union. London: Macmillan.

Inglehart R and Norris P (2003) Rising Tide: Gender Equality and Cultural Change around the World. New York: Cambridge University Press.

Iversen T and Rosenbluth F (2008) Work and power: The connection between female labour force participation and female political participation. Annual Review of Political Science 11: 479-495.

Iversen T and Soskice D (2006) Electoral institutions and the politics of coalitions: Why some democracies distribute more than others. American Political Science Review 100(2): $165-181$.

Jones M (2009) Gender quotas, electoral laws, and the election of women. Comparative Political Studies 42(1): 56-81.

Kantola J (2010) Gender and the European Union. Houndmills: Palgrave MacMillan.

Katz R (1997) Democracy and Elections. Oxford: Oxford University Press.

Kenworthy L and Malami M (1999) Gender inequality in political representation: A worldwide comparative analysis. Social Forces 78(1): 235-268.

Krook ML (2002) Europe for women, women for Europe. In: Micgiel JS (ed.) Democracy and Integration in the European Union. New York: Institute for the Study of Europe, pp. 67-86.

Krook ML (2009) Quotas for Women in Politics. Gender and Candidate Selection Reform Worldwide. Oxford: Oxford University Press.

Krook ML (2010) Women's representation in parliament: A qualitative comparative analysis. Political Studies 58(5): 886-908.

Kunovich S and Paxton P (2005) Pathways to power: The role of political parties in women's national political representation. American Journal of Sociology 111(2): 505-552.

Lakeman E (1994) Comparing political opportunities in Great Britain and Ireland. In: Rule $\mathrm{W}$ and Zimmerman JF (eds) Electoral Systems in a Comparative Perspective. Their Impact on Women and Minorities. Westport and London: Greenwood Press, pp. 15-30.

Lane JC (1995) The election of women under proportional representation: The case of Malta. Democratization 2(2): 140-157.

Lijphart A (1984) Democracies: Patterns of Majoritarian and Consensus Government in Twenty-One Countries. New Haven, CT: Yale University Press. 
Lijphart A (1986) Degrees of proportionality of proportional representation formulas. In: Grofman B and Lijphart A (eds) Electoral Laws and Their Political Consequences. New York: Agathon Press, pp. 170-182.

Lijphart A (1999) Patterns of Democracy. Government Forms and Performances in Thirty-Six Countries. New Haven, CT: Yale University Press.

Lipset SM and Rokkan S (1967) Cleavage structures, party systems and voter alignments. Introduction. In: Lipset SM and Rokkan S (eds) Party Systems and Voter Alignments: Cross-National Perspectives. New York: The Free Press, pp. 1-64.

Lipson L (1964) The Democratic Civilization. New York: Oxford University Press.

Manow P and Döring H (2008) Electoral and mechanical causes of divided government in the European Union. Comparative Political Studies 41(10): 1349-1370.

Marks G and Steenbergen M (2002) Understanding political contestation in the European Union. Comparative Political Studies 38(8): 879-892.

Mateo Diaz M (2005) Representing Women? Female Legislators in West European Parliaments. Colchester: ECPR press.

Mather J (2001) The European Parliament: A model of representative democracy? West European Politics 24(1): 181-201.

Matland RE (1993) Institutional variables affecting female representation in national legislatures: The case of Norway. Journal of Politics 55(3): 737-755.

Matland RE (1998) Women's representation in national legislatures: Developed and developing countries. Legislative Studies Quarterly 23(1): 109-125.

Matland RE (2005) Enhancing women's political participation: Legislative recruitment and electoral systems. In: Karam A and Ballington J (eds) Women in Parliament: Beyond Numbers. Stockholm: International IDEA, pp. 93-131.

Matland RE and Studlar DT (1996) The contagion of women candidates in single-member district and proportional representation electoral systems: Canada and Norway. Journal of Politics 58(3): 707-733.

McAllister I and Studlar DT (2002) Electoral systems and women's representation: A long term perspective. Representation 39(1): 3-14.

McElroy G and Benoit K (2007) Party groups and policy positions in the European Parliament. Party Politics 31(1): 5-28.

McElroy G and Marsh M (2010) Candidate gender and voter choice: Analysis from a multimember preferential voting system. Political Research Quarterly 63(4): 822-833.

Mezey S (1980) Perception of women's roles on local councils in Connecticut. In: Stewart D (ed.) Women in Local Politics. Metuchen, NJ: Scarecrow Press, pp. 61-85.

Moser RG (2001) The effects of electoral systems on women's representation in postcommunist states. Electoral Studies 20(3): 273-292.

Moser RG and Scheiner E (2012) Electoral Systems and Political Context: How the Effects of Rules Vary Across New and Established Democracies. Cambridge: Cambridge University Press.

Murray R (2010) Parties, Gender Quotas and Candidate Selection in France. Basingstoke: Palgrave.

Niven D (1998) Party elites and women candidates. Women \& Politics 19(2): 57-80.

Norris P (1985) Women's legislative participation in Western Europe. Western European Politics 8(4): 90-101.

Norris P (1996) Legislative recruitment. In: LeDuc L, Niemi RG and Norris P (eds) Comparing Democracies: Elections and Voting in a Global Perspective. Thousand Oaks, CA: Sage, pp. 184-215. 
Norris P (1997) Conclusions. Comparing passages to power. In: Norris P (ed.) Passages to Power. Legislative Recruitment in Advanced Democracies. Cambridge: Cambridge University Press, pp. 209-231.

Norris P (2004) Electoral Engineering. Voting Rules and Political Behavior. New York: Cambridge University Press.

Norris P and Franklin M (1997) Social representation. European Journal of Political Research 32(2): 185-210.

Norris P and Krook ML (2011) Gender equality in elected office: A six-step action plan. Baseline study for the OSCE/ODIHR Handbook on Measures to Promote Women's Participation in Political Parties.

Oakes A and Almquist E (1993) Women in national legislatures. Population Research and Policy Review 12(1): 71-81.

Odershook P and Shvetsova O (1994) Ethnic heterogeneity, district magnitude and the number of parties. American Journal of Political Science 38(1): 100-123.

Paxton P (1997) Women in national legislatures: A cross national analysis. Social Science Research 26(4): 442-464.

Paxton P and Hughes MM (2007) Women, Politics, and Power: A global Perspective. Thousand Oaks, CA: Pine Forge Press.

Paxton P and Kunovich S (2003) Women's political representation: The importance of ideology. Social Forces 82(1): 87-113.

Persson T and Tabellini G (2003) The Economic Effects of Constitutions. Cambridge, MA: MIT Press.

Phillips A (1995) The Politics of Presence. Oxford: Clarendon Press.

Pitkin HF (1967) The Concept of Representation. Berkeley: University of California Press.

Pollack MA and Hafner-Burton E (2000) Mainstreaming gender in the European Union. Journal of European Public Politics 7(3): 432-456.

Reif K and Schmitt H (1980) Nine-second order national elections. European Journal of Political Research 8(1): 3-44.

Reynolds A (1999) Women in the legislatures and executives of the world knocking at the highest glass ceiling. World Politics 51(4): 547-572.

Reynolds A and Reilly B (1997) The International IDEA Handbook of Electoral System Design. Stockholm: International Institute for Democracy and Electoral Assistance.

Rittberger B (2005) Building Europe's Parliament. Democratic Representation Beyond the Nation State. Oxford: Oxford University Press.

Roberts A, Seawright J and Cyr J (2013) Do electoral laws affect women's representation? Comparative Political Studies 46(12): 1555-1581.

Rokkan S (1970) Citizens, Elections, Parties. Oslo: Universitetsforlaget.

Rosenbluth F and Salmond R (2006) Welfare works: Explaining female legislative representation. Politics \& Gender 2(2): 165-192.

Rule W (1987) Electoral systems, contextual factors, and women's opportunity for election to parliament in twenty-three democracies. Western Political Quarterly 40(3): 477-498.

Rule W (1994) Women's underrepresentation and electoral systems. PS: Political Science and Politics 27(4): 689-692.

Salmond R (2006) Proportional representation and female parliamentarians. Legislative Studies Quarterly 31(2): 175-204.

Schmidt G (2008) The election of women in list PR systems: Testing the conventional wisdom. Electoral Studies 28(2): 190-203. 
Schwindt-Bayer LA and Mishler W (2005) An integrated model of women's representation. The Journal of Politics 67(2): 407-428.

Shugart M (1994) Minorities represented and unrepresented. In: Rule W and Zimmerman JF (eds) Electoral Systems in Comparative Perspective: The Impact on Women and Minorities. Westport, CT: Westview Press, pp. 31-41.

Siaroff A (2000) Women's representation in legislatures and cabinets in industrial democracies. International Political Science Review 21(2): 197-215.

Stockemer D (2008) Women's representation in Europe - A comparison between the national parliaments and the European Parliament. Comparative European Politics 6(4): 463-485.

Studlar DT and McAllister I (1991) Political recruitment to the Australian legislature: Toward an explanation of women's electoral disadvantages. Western Political Quarterly 44(2): 467-485.

Studlar DT and Welch S (1991) Does district magnitude matter? Women candidates in London local elections. Western Political Quarterly 44(2): 457-466.

Taagepera R (1994) Beating the law of minority attrition. In: Rule W and Zimmerman JF (eds) Electoral Systems in Comparative Perspective. Their Impact on Women and Minorities. Westport: Greenwood Press, pp. 235-246.

Taagepera R (1998) Effective magnitude and effective threshold. Electoral Studies 17(4): 393-404.

Taagepera R (2007) Predicting Party Sizes: The Logic of Simple Electoral Systems. Oxford: Oxford University Press.

Thames FC and Williams MS (2010) Incentives for personal votes and women's representation in legislatures. Comparative Political Studies 43(12): 1575-1600.

Tripp AM and Kang A (2008) The global impact of quotas: The fast track to female representation. Comparative Political Studies 41(3): 338-361.

Valdini ME (2012) A deterrent to diversity: The conditional effect of electoral rules on the nomination of women candidates. Electoral Studies 31(4): 740-749.

Vallance E and Davis E (1986) Women of Europe. Cambridge: Cambridge University Press.

Vengroff R, Creevey L and Krisch H (2000) Electoral system effects on gender representation. Japanese Journal of Political Science 1(2): 197-222.

Wangnerud L (2009) Women in parliaments: Descriptive and substantive representation. Annual Review of Political Science 12: 51-69.

Welch S and Studlar DT (1986) British public opinion towards women in politics: A comparative perspective. Western Political Quarterly 39(1): 138-154. 